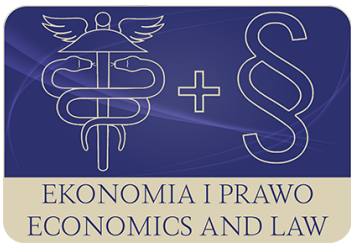

EKONOMIA I PRAWO. ECONOMICS AND LAW

Volume 19, Issue 1, March 2020

p-ISSN 1898-2255, e-ISSN 2392-1625

www.economicsandlaw.pl

ORIGINAL ARTICLE

received 13.07.2019; revised 11.01.2020; accepted 31.03.2020

Citation: Szczepaniak, M. (2020). Redistribution and the alleviation of income inequalities: the case of the European Union. Ekonomia i Prawo. Economics and Law, 19(1): 149-161. doi:10.12775/EiP.2020.011.

\title{
Redistribution and the alleviation of income inequalities: the case of the European Union
}

\author{
MAEGORZATA SZCZEPANIAK \\ Nicolaus Copernicus University in Torun, Faculty of Economics Sciences and Management, \\ Department of Economics, ul. Gagarina 11, 87-100 Torun, Poland \\ 曰m.szczepaniak@umk.pl \\ (D) orcid.org/0000-0001-6007-8430
}

\begin{abstract}
Motivation: The income inequalities are considered an important economic and social problem, because increasing income inequalities may make it difficult to achieve such policy goals as: social cohesion and inclusive development. State's interference through

redistribution is aimed to decrease the differences between the rich and poor. Even though social transfers alleviate the income inequalities, the extent to which they decrease the gap between the rich and the poor is different in European Union (EU) countries. The answer to the question of redistribution effectiveness is extremely important from this perspective.
\end{abstract}

Aim: The article aims to present the diversity of EU countries from the perspective of income inequalities, social transfers (government expenditures on social protection, health and education) and finally redistribution. Its aim is also to assess the impact of social transfers on inequalities on the basis of dynamic panel data model.

Results: There is no significant relationship between the level of social transfers and Gini disposable income. However, the results of regression analysis proved that government expenditures on social protection significantly increase the difference between market and disposable income inequalities (Gini gap) and therefore more effectively decrease income inequalities.

Keywords: income inequalities; redistribution; social transfers

JEL: D31; D63; H23; H53 


\section{Introduction}

Achieving goals such as sustainable growth and socio-economic development ensuring social inclusion, reducing poverty and reducing inequalities is among the most important policy aims worldwide nowadays (Sachs, 2012). State's redistribution policies (taxes and social transfers) are an important factor in the process of implementing these strategies, shaping the gap between the rich and the poor in each society.

Income inequalities are multidimensional issue. Among many factors that affect inequalities it is the state's redistributional policy that is one of the most important. The relatively high redistribution in Europe in comparison to the largest other major OECD economies is characteristic for this region's welfare system (Bussolo et.al., 2018). However social transfers tackle inequalities to different extent across EU countries. The in-depth analysis, when the particular kinds of transfers (on social protection, health and education) are considered, revealed that also the structure of these transfers differs across the EU countries. Therefore, there are important questions the article aims to answer: If higher social transfers decrease income inequalities more effectively? What kind of social transfers (social protection, health, housing or education) most effectively reduce income inequalities?

Even though the comparison of the two Gini measures (Gini calculated on income market income and Gini calculated on equivalized disposable incomel) gives the information about the extent to which social transfers decrease inequality in particular country, there's a lack of research that provides results for state's policy implications to counteract inequalities through income redistribution.

From this perspective, the aims of the article are: to present the diversity of EU Union countries regarding to both income inequalities and redistribution and to identify the redistribution effectiveness in decreasing income inequalities through social transfers. In order to assess the impact of social transfers on inequalities panel data model was used. Therefore, this paper provides the identification of different kind of social policies (social protection, education, health) that affects inequalities to the highest extent.

The remainder of this article is organized as follows. After the short review of the recent literature on relationships between inequalities and redistribution policies, trends in inequalities across EU countries from the perspective of Gini market income and Gini disposable income are presented. Both the level of social transfers and the distribution are considered in relation to income inequalities. A final section discusses conclusions on the basis of the panel data model results.

1 The concept of household adjusted disposable income frames individuals consumption possibilities that's why it is used to calculate Gini disposable income indices. It also considers education, health, housing and family policies (OECD, 2012; Szczepaniak, 2018). 


\section{Literature review}

The distributional role of transfers is one of the factors (among the influence the institutions on labour market, skill differentials, education and health policies) that should be taken into consideration when inequalities changes are analysed (Atkinson, 1996). In this aspect, the problem of effectiveness of redistribution in a broad perspective, including government expenditures on social protection ${ }^{2}$, health, housing and education is extremely important and interesting field of research. However, the identification of particular social transfers and their role on decreasing income inequalities is the problem which is not clearly resolved in the literature.

Even though there is a growing concern about the negative impact of high income inequalities on standard of living of individuals the most of the analyses regards the relationships between the income inequalities and dynamics of growth and development (Easterly, 2007; OECD, 2015). Income inequalities are also identified as a source of political instability (Stiglitz, 2013).

However, when different time approaches are considered the picture is blurred. In the long run consequences of the high redistribution (high nonconditional social benefits) create strong disincentive to work and increase the unemployment rate, increase government expenditures and decrease the disposable income of households and therefore increase inequalities (Roed \& Strom, 2002). On the other hand, there is strong believe that government is able to effectively tackle income inequalities in the short run through expansion of government expenditures and taxes. In according to theses conceptions major functions of the welfare state is to redistribute income collected through taxation via government expenditures on social protection, health, education, housing (Atkinson, 1996; OECD, 2012).

After crisis of 2008 the issues of income inequalities were also considered from the perspective of impact the use of discretionary fiscal policy actions which result in higher redistribution on inequalities. Rising income inequalities because of stronger discretionary policy calls are more likely to result in financial crisis. What is more, if fiscal policies effectively reduce debt-to-GDP ratio, they help to avoid political instability connected with high income inequalities (Agnello et al., 2017).

The redistribution issues are also analysed from the comparative perspective of taxes and transfers effectiveness in decreasing income inequalities. However, transfers are the most important source of redistribution (Fuest et. al., 2010) and significantly reduce income inequalities (Afonso et al., 2010). What is more when particular kind of social transfers are considered, education expenditures did not significantly affect income inequalities and health benefits

${ }^{2}$ Government expenditures on social protection includes e.g. unemployment benefits, old age and survivors' benefits, sickness benefits, education related allowances, family and children related allowances, social exclusion, etc. The specification of particular kinds of these expenditures can be found in Eurostat (2011, pp. 180-183). 
negatively affected Gini coefficient of equivalised income (Dorrenberg \& Peichl, 2014; Niehues, 2010). Moreover social expenditures are more efficient in inequality reduction than taxes. On average in according to OECD (2012) report, three quarters of the reduction in inequality is due to transfers, the rest to direct household taxation.

This article aims at contributing to this discussion from and empirical perspective, based on the data available from Eurostat (2019) database and OECD (2019) Income Distribution Database for the period of 2007-2016.

\section{Data analysis}

Social policy (social protection, educational, housing and health policy) encompasses a broad range of public actions that provide direct support to people to help them deal with vulnerability, exclusion, inequalities and poverty. This reflects government's core function to redistribute income and wealth, financed by compulsory payments.

Government's expenditures on social protection had highest share in government expenditures in the EU countries (45\% on average). Together with expenditures on education and health and housing they stood on average at level of $70 \%$ of total expenditures in EU countries. However, there were disparities between analysed countries identified, e.g.: in 2016 the share of government expenditures on social protection in total expenditures ranged from $26 \%$ in Ireland to $57 \%$ in France (table 1). Expenditures on social protection increased in most countries during the economic crisis in 2008. When expenditures on education and health are analysed this trend is not so clear. However, the role of redistributive policies have developed since the crisis and partly in response to it (Jenkins et. al., 2011).

Disparities between EU countries were also observed when both Gini measures (Gini calculated on the basis of income before taxes and transfers and Gini calculated on the basis of income after taxes and transfers) were taken into consideration in the analysed period.

Disposable income inequalities ranged between 24 in Slovak Republic to 38 in Lithuania in 2016. A decade earlier, in 2007, Latvia was the country characterized by highest level of disposable income inequalities and Slovenia was the most equal country. What is interesting, when market income inequalities were analysed, the disparities were lower. The highest level of disposable income inequalities is 1.6 times higher; the highest level of market income inequalities is only 1.4 higher. Gini index before taxes and transfers ranged between 34 in Slovak Republic to 49 in Ireland in 2016. In 2007 it was the lowest in Slovak Republic and Ireland were the countries with highest market income inequalities. The relative differences in how taxes and transfers decrease the Gini gap (difference between Gini before transfer and taxes and Gini after taxes and transfers) are described by effectiveness of redistribution (table 2). 
Redistribution is measured by comparison of Gini coefficient before taxes and transfers and Gini coefficient after taxes and transfers (Gini gap) and is quantified as the relative reduction in market income inequality achieved by personal income taxes and social transfers (Causa \& Hamersen, 2017).

$$
\frac{\text { Gini }_{\text {before taxes and transfers }}-\text { Gini }_{\text {after taxes and transfers }}}{\text { Gini }_{\text {before taxes and transfers }}} \cdot 100 .
$$

Taxes and transfers redistribute income from richer to poorer households in all EU countries. However equalising effect of taxes and transfers varies widely across the EU even for similar levels of inequality before taxes and transfers. The extent of redistribution differs across EU countries. It is the lowest in Baltic countries (15\% in 2016), the highest in Finland and Ireland (40\% in 2016) (table 2, chart 1)

Redistribution increased in most EU countries, to the highest extent in Spain, Portugal, Finland and Ireland (5-7 p.p.) and decreased only in 5 countries (Sweden -7 p.p., Lithuania -4 p.p., Slovak Republic and Czech Republic -3 p.p.) between 2007 and 2016.

Redistribution of income in EU countries varied from the lowest level in Baltic countries (Latvia 11\%, Estonia 18\%, Lithuania 19\%) to Slovenia (37\%), Ireland and Finland (35\% in both countries) in 2007 (27\% on average in EU). After the economic crisis redistribution increased to the average level of $29 \%$ in EU countries. It ranged from $15 \%$ in Latvia and Lithuania to $40 \%$ in Ireland and Finland in 2016.

The level of redistribution should not be misled with the level of inequalities, however (chart 2). Ireland is the country with the highest level of market income inequalities and average level of disposable income inequalities even though the highest redistribution (40\%). Slovak Republic and Czechia can be characterized with average redistribution level (30\%), however one of the lowest disposable income inequalities (24 and 25 respectively). What is more, in Greece and Ireland, the countries with the similar level of market income inequalities (Greece - 48 and Ireland - 50), because of different redistribution (30\% and $40 \%$ respectively) - disposable income inequalities were lower in Ireland than in Greece (Ireland 30, Greece 33). The similar situation can be observed when France and United Kingdom are compared - with similar levels of market income inequalities (45 in both countries), because of different redistribution (36\% and 23\% respectively) disposable income inequalities were lower in France (29) than in United Kingdom (35) (chart 2). Similarly, the two countries with comparable level of disposable income inequalities, for instance Poland (28) and Sweden (28), are described with higher level of market income inequalities (41) and redistribution (31\%) in Poland than in Sweden (37\%; 23\% respectively) in 2016. To conclude, equalizing effect of taxes and transfers varies widely in selected EU countries. Even for similar levels of market income inequalities redistribution differs across analysed countries. 
The Pearson correlation coefficient was calculated in order to assess the relationship between inequalities and redistribution. There is a significant negative relationship between redistribution (in \%) and Gini disposable income coefficient $(-0.7)$. However, there was no significant relationship between the level of government expenditures on social protection and disposable income and market income Gini indices. That's why the panel model data analysis was built in order to conduct the in-depth analysis.

\section{Method and results}

Panel data have both cross-sectional and time-series dimensions (Osińska, 2007). Panel data provide information on government expenditures and inequalities across EU countries and over time. UE-25 countries (EU-29 without Bulgaria, Romania, Croatia and Luxembourg) were analysed in the period of 13 years between 2005 and 2017.

The panel data model (random effects) was estimated, where GiniGap ${ }_{i, t}$ denotes, for each $i$-th country at time $t$ included in the sample, difference between the Gini calculated on before taxes and transfers incomes and Gini calculated on after taxes and transfers incomes; housing ${ }_{i, t}$ denotes the government ex-

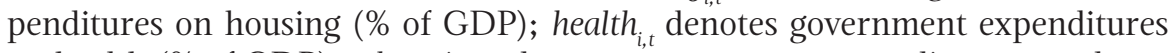
on health (\% of GDP); education ${ }_{i, t}$ denotes government expenditures on education (\% of GDP) and socialprotection ${ }_{i, t}$ denotes government expenditures on social protection (\% of GDP). Each explanatory variable is instrumented with its own two lags.

$$
\begin{aligned}
& \text { GiniGap }_{i, t}=\alpha+\beta_{1} \text { housing }_{i, t}+\beta_{2} \text { housing }_{i, t-1}+\beta_{3} \text { housing }_{i, t-2}+ \\
& +\beta_{4} \text { health }_{i, t}+\beta_{5} \text { health }_{i, t-1}+\beta_{6} \text { health }_{i, t-2}+\beta_{7} \text { education }_{i, t}+ \\
& +\beta_{8} \text { education }_{i, t-1}+\beta_{9} \text { education }_{i, t-2}+\beta_{10} \text { socialprotection }_{i, t}+ \\
& +\beta_{11} \text { socialprotection }_{i, t-1}+\beta_{12} \text { socialprotection }_{i, t-2}+\varepsilon_{i, t}
\end{aligned}
$$

Table 3 reports the estimated coefficients. Only housing, first lag of health and social protection expenditures (first and second lag) significantly affected Gini gap. Their signs differed however. Empirical findings showed that housing expenditures contributed to the decrease in the Gini gap. If there was increase in housing expenditures, the taxes and transfers decreased inequalities to lower extent. Similar results were identified for health expenditures. Housing and health expenditures proved to be not effective in the income inequalities alleviation. What is more, surprisingly education expenditures did not significantly affect the redistribution. However increase in the human capital may result in higher income of individuals in the long time. Regarding effects of government expenditures on social protection the results revealed that when the social protection expenditures increased, the Gini gap increased so taxes and transfers decreased inequalities to higher extent. Therefore only expenditures on social protection worked in the desired direction - increased the redistribution 
(in \%). Individual effects were the highest in Czechia, Ireland and Sweden but the lowest in Italy.

$$
\begin{aligned}
& \text { GiniGap }_{i, t}=\alpha+\beta_{I} \text { GiniGap }_{i, t-1}+\beta_{2} \text { housing }_{i, t}+\beta_{3} \text { housing }_{i, t-1}+ \\
& +\beta_{4} \text { housing }_{i, t-2}+\beta_{5} \text { health }_{i, t}+\beta_{6} \text { health }_{i, t-1}+\beta_{7} \text { health }_{i, t-2}+ \\
& +\beta_{8} \text { education }_{i, t}+\beta_{9} \text { education }_{i, t-1}+\beta_{10} \text { education }_{i, t-2}+ \\
& +\beta_{I l} \text { socialprotection }_{i, t}+\beta_{12} \text { socialprotection }_{i, t-1}+ \\
& +\beta_{13} \text { socialprotection }_{i, t-2}+\varepsilon_{i, t} .
\end{aligned}
$$

The dynamic panel data model with lagged dependent variable revealed that housing and health expenditures did not significantly affect income inequalities. Education expenditures were not significantly related to Gini gap too. However total impact of social protection expenditures on Gini gap was significant and positive. The higher the level of social protection expenditures the higher the difference between the before and after transfers inequalities and lower disposable income inequalities. Regarding to the significant contribution of lagged GiniGap, results revealed that there was an innertia phenomenon. 35\% of previous inequalities significantly affected the present inequalities (table 4). Actually, it can be associated with the impact of the housing and health policies from the previous periods.

Alleviation of inequalities requires the long-term policy strategy because of the interrelationships across the social policies (social protection, housing, health and education) and relatively long period of their implementation. Even though only social protection expenditures had a direct significant statistical impact on redistribution, other social policies (educational, housing, health) contribute to improving the standard of living, material status, quality of life and indirectly alleviate the inequalities through the better possibilities to be healthier and to get a better job in the future. The indirect impact is reflected by the phenomenon of inertia described by the model.

\section{Conclusions}

Even though the answer to the question if income redistribution alleviate income inequalities across EU countries seems to be obvious, the need of in-depth analysis was proved. The results of the analysis showed that even though taxes and transfers decrease income inequalities in all countries the extent of this reduction differs across the analysed group of countries. What is more, different kinds of social transfers were analysed. As a result of the dynamic panel data model the total impact of expenditures on social protection on Gini gap was significant and positive. Other kinds of expenditures (health, housing, education) did not significantly affect Gini Gap however. Additionally, the impact of lagged dependent variable was significant. It means that the alleviation of income inequalities is especially important because they are transferred from 
one to the next period. On the other side they can reflect the indirect impact of the other social policies.

Finally, the results of the research showed that social protection expenditures significantly affected Gini gap. The increase in social protection expenditures increased the extent of redistribution - as a result the disposable income inequalities decrease. However, alleviation of income inequalities supported by aligning redistribution policies requires spending in the right areas. Indeed, the careful defining of the social transfers must be taken into consideration. Constraints of research's conclusions are connected with the fact that social policies are expected to have a positive effect on market income inequalities suggesting causal effects of social spendings and income inequalities (Niehues, 2010). That's why the research does not exhaust the subject and will be continued in the direction of the causal relationships between social transfers and income inequalities.

\section{References}

Afonso, A., Schuknecht, L., \& Tanzi, V. (2010). Income distribution determinants and public spending efficiency. Journal of Economic Inequality, 8(3). doi:10.1007/s10888-010-9138-z.

Agnello, L., Castro, V., Jalles, J.T., \& Sousa, R.M. (2017). Income inequality, fiscal stimuli and political (in)stability. International Tax Public Finance, 24(3). doi:10.1007/s10797-016-9428-x.

Atkinson, A. (1996). Seeking to explain the distribution of income. In J. Hills (Ed.), New inequalities: the changing distribution of income and wealth in the United Kingdom. Cambridge-New York: Cambridge University Press. doi:10.1017/CBO9780511521935.002.

Bussolo, M., Krolage, C., Makovec, M., Peichl, A., Stockli, M., Torre, I., \& Wittneben, C. (2018). Vertical and horizontal redistribution: the case of Western and Eastern Europe. Policy Research Working Papers, 275. doi:10.1596/1813-9450-8657.

Causa, O., \& Hermansen, M. (2017). Income redistribution through taxes and transfers across OECD countries. OECD Economics Department Working Papers, 1453. doi:10.1787/bc7569c6-en.

Dorrenberg, P., \& Peichl, A. (2014). The impact of redistributive policies on inequality in OECD countries. Applied Economics, 46(17). doi:10.1080/00036 846.2014.892202.

Easterly, W. (2007). Inequality does cause underdevelopment: insights from a new instrument. Journal of Development Economics, 84(2). doi:10.1016/j. jdeveco.2006.11.002.

Eurostat. (2011). Manual on sources and methods for the compilation of COFOG statistics: classification of the functions of government (COFOG). doi:10.2785/16355.

Eurostat. (2019). Retrieved 10.01.2020 from https://ec.europa.eu. 
Fuest, C., Niehues, J., \& Peichl, A. (2010). The redistributive effects of tax benefit systems in the enlarged EU. Public Finance Review, 38(4). doi:10.1177/1091142110373480.

Jenkins, S.P., Brandolini, A., Micklewright, J., \&Nolan, B. (2011). The great recession and the distribution of household income. Oxford: Oxford University Press. doi:10.1093/acprof:oso/9780199671021.001.0001.

Niehues, J. (2010). Social spending generosity and income inequality: a dynamic panel model approach. IZA Discussion Paper Series, 5178. doi:10.2139/ ssrn. 1724733.

OECD. (2012). Income inequality and growth: the role of taxes and transfers. OECD Economics Department Policy Notes, 9.

OECD. (2015). In it together: why less inequality benefits all? Paris: OECD Publishing. doi:10.1787/9789264235120-en.

OECD. (2019). Retrieved 10.01.2020 from https://www.oecd.org.

Osińska, M. (Ed.). (2007). Ekonometria wspótczesna. Torun: TNOiK.

Roed, K., \& Strom, S. (2002). Progressive taxes and the labour market: Is the trade-off between equality and efficiency inevitable? Journal of Economic Surveys, 16(1). doi:10.1111/1467-6419.00160.

Sachs, J.P. (2012). From millennium development goals to sustainable development goals. Lancet, 379(9832). doi:10.1016/s0140-6736(12)60685-0.

Stiglitz, J.E. (2013). The price of inequality: how today's divided society endangers our future. New York: W.W. Norton \& Company.

Szczepaniak, M. (2018). Nierówności dochodowe w wybranych krajach na tle systemów społeczno-gospodarczych. Nierówności Spoteczne a Wzrost Gospodarczy, 55(3). doi:10.15584/nsawg.2018.3.11.

\section{Acknowledgements}

Author contributions: author has given an approval to the final version of the article.

Funding: this research was funded by the Nicolaus Copernicus University of Torun, Faculty of Economic Sciences and Management statutory sources.

Note: the results of this study were presented at 8th International Scientific Conference: Contemporary Economic Problems 'Social-economic problems in the era of globalization: theory and practice' (May, 22, 2019, Torun, Poland). 


\section{Appendix}

Table 1.

Government expenditures on social protection, education, health, housing in 2007 and 2016 in EU countries (in \% of GDP)

\begin{tabular}{|c|c|c|c|c|c|c|c|c|}
\hline \multirow{2}{*}{ Country* } & \multicolumn{2}{|c|}{ Social protection } & \multicolumn{2}{|c|}{ Education } & \multicolumn{2}{|c|}{ Health } & \multicolumn{2}{|c|}{ Housing } \\
\hline & 2007 & 2016 & 2007 & 2016 & 2007 & 2016 & 2007 & 2016 \\
\hline Ireland & 13.1 & 10.0 & 4.3 & 3.3 & 6.2 & 5.2 & 1.7 & 0.5 \\
\hline Lithuania & 10.7 & 11.2 & 5.3 & 5.1 & 5.2 & 5.8 & 0.3 & 0.4 \\
\hline Malta & 13.4 & 11.6 & 5.2 & 5.2 & 5.5 & 5.4 & 0.6 & 0.3 \\
\hline Latvia & 7.9 & 12.0 & 5.6 & 5.5 & 4.0 & 3.7 & 1.2 & 0.9 \\
\hline Czechia & 11.9 & 12.3 & 4.7 & 4.5 & 6.8 & 7.4 & 1.0 & 0.6 \\
\hline Estonia & 9.3 & 13.2 & 5.9 & 5.8 & 4.3 & 5.2 & 0.6 & 0.3 \\
\hline Cyprus & 10.0 & 13.5 & 5.9 & 5.9 & 2.6 & 2.6 & 2.3 & 1.5 \\
\hline Hungary & 17.2 & 14.5 & 5.5 & 4.9 & 4.9 & 4.8 & 1.0 & 0.7 \\
\hline Slovakia & 13.2 & 15.1 & 3.5 & 3.8 & 6.1 & 7.4 & 0.6 & 0.5 \\
\hline United Kingdom & 14.3 & 15.8 & 5.6 & 4.8 & 6.5 & 7.6 & 1.2 & 0.6 \\
\hline Netherlands & 14.4 & 16.4 & 5.0 & 5.2 & 6.7 & 7.5 & 0.5 & 0.3 \\
\hline Poland & 15.6 & 16.6 & 5.7 & 5.0 & 4.5 & 4.6 & 1.1 & 0.6 \\
\hline Slovenia & 15.2 & 16.8 & 5.9 & 5.5 & 5.8 & 6.7 & 0.6 & 0.4 \\
\hline Spain & 12.8 & 16.9 & 4.0 & 4.0 & 5.7 & 6.1 & 0.9 & 0.4 \\
\hline Portugal & 14.8 & 18.0 & 6.2 & 4.8 & 7.1 & 6.0 & 0.8 & 0.5 \\
\hline EU average & 17.0 & 19.0 & 4.9 & 4.7 & 6.5 & 7.1 & 0.9 & 0.6 \\
\hline Germany & 18.7 & 19.3 & 3.9 & 4.1 & 6.3 & 7.1 & 0.8 & 0.4 \\
\hline Belgium & 16.7 & 19.6 & 5.5 & 6.3 & 6.7 & 7.7 & 0.4 & 0.3 \\
\hline Greece & 15.7 & 20.4 & 3.6 & 4.0 & 6.0 & 5.0 & 0.2 & 0.2 \\
\hline Sweden & 20.2 & 20.7 & 6.3 & 6.7 & 6.4 & 6.9 & 0.7 & 0.7 \\
\hline Italy & 17.5 & 21.0 & 4.5 & 3.8 & 6.7 & 6.9 & 0.7 & 0.6 \\
\hline Austria & 19.4 & 21.1 & 4.7 & 4.9 & 7.4 & 8.2 & 0.4 & 0.4 \\
\hline Denmark & 21.5 & 23.0 & 5.9 & 6.8 & 7.7 & 8.5 & 0.3 & 0.3 \\
\hline France & 21.7 & 24.5 & 5.3 & 5.5 & 7.5 & 8.1 & 1.2 & 1.1 \\
\hline Finland & 19.2 & 25.6 & 5.8 & 6.1 & 6.6 & 7.2 & 0.3 & 0.3 \\
\hline
\end{tabular}

Notes:

* Countries were ordered by the level of expenditures on social protection in 2016.

Source: Own preparation based on Eurostat (2019). 
Table 2.

Before and after taxes and transfers inequalities and redistribution in selected EU countries and UE average in 2007 and 2016

\begin{tabular}{lcccccc}
\hline \multirow{2}{*}{ Country* } & \multicolumn{2}{c}{ Gini before TT** } & \multicolumn{2}{c}{ Gini after TT*** } & \multicolumn{2}{c}{ Redistribution (in \%) } \\
\cline { 2 - 6 } Slovak Republic & 2007 & 2016 & 2007 & 2016 & 2007 & 2016 \\
Slovenia & 36.2 & 34.3 & 24.5 & 24.1 & 32.3 & 29.7 \\
Czech Republic & 37.8 & 39.2 & 23.9 & 24.4 & 36.8 & 37.8 \\
Finland & 38.9 & 36.5 & 25.6 & 25.3 & 34.2 & 30.7 \\
Denmark & 41.5 & 43.3 & 26.9 & 25.9 & 35.2 & 40.2 \\
Belgium & 37.0 & 41.0 & 24.6 & 26.3 & 33.5 & 35.9 \\
Sweden & 41.1 & 42.4 & 27.7 & 26.6 & 32.6 & 37.3 \\
Austria & 36.8 & 36.6 & 25.9 & 28.2 & 29.6 & 23.0 \\
Poland & 42.3 & 43.0 & 28.4 & 28.4 & 32.9 & 34.0 \\
Netherlands & 44.7 & 41.0 & 31.6 & 28.4 & 29.3 & 30.7 \\
France & 39.5 & 40.8 & 29.5 & 28.5 & 25.3 & 30.1 \\
Germany & 43.1 & 45.2 & 29.2 & 29.1 & 32.3 & 35.6 \\
Ireland & 40.8 & 41.5 & 29.5 & 29.4 & 27.7 & 29.2 \\
Estonia & 46.8 & 49.8 & 30.4 & 29.7 & 35.0 & 40.4 \\
Italy & 38.2 & 38.1 & 31.2 & 31.4 & 18.3 & 17.6 \\
Portugal & 41.8 & 44.1 & 31.3 & 32.8 & 25.1 & 25.6 \\
Greece & 45.9 & 46.5 & 36.1 & 33.1 & 21.4 & 28.8 \\
Spain & 44.3 & 47.5 & 32.9 & 33.3 & 25.7 & 29.9 \\
Latvia & 39.7 & 46.1 & 32.4 & 34.1 & 18.4 & 26.0 \\
United Kingdom & 41.8 & 40.7 & 37.4 & 34.6 & 10.5 & 15.0 \\
Lithuania & 41.9 & 45.4 & 37.3 & 35.1 & 20.1 & 22.7 \\
\hline
\end{tabular}

Notes:

* Countries were ordered by the level of Gini after TT; ** Gini before taxes and transfers (market income inequalities); ${ }^{* *}$ Gini after taxes and transfers (disposable income inequalities).

Source: Own preparation based on OECD (2019).

Table 3.

\section{Random effects estimation}

\begin{tabular}{lccc}
\hline \multicolumn{1}{c}{ Variables } & Coefficient & Standard error & p-value \\
\hline const & 10.2285 & 1.7196 & $<0.0001$ \\
housing & -1.8761 & 0.5404 & 0.0005 \\
health_1 & -1.2106 & 0.2367 & $<0.0001$ \\
socialprotection_1 & 0.7106 & 0.1257 & $<0.0001$ \\
socialprotection_2 & 0.3609 & 0.1161 & 0.0019 \\
\hline
\end{tabular}

Notes:

Number of observations $=275,25$ cross -sectional data units enabled, time series length $=11$, dependent variable: GiniGap.

Source: Own preparation. 
Table 4.

Dynamic panel data model estimation of a 1-step panel with lagged dependent variable

\begin{tabular}{lccc}
\hline \multicolumn{1}{c}{ Variables } & Coefficient & Standard error & p-value \\
\hline GiniGap(-1) & 0.3491 & 0.1219 & 0.0042 \\
const & 0.0179 & 0.0413 & 0.6652 \\
socialprotection_1 & 0.4913 & 0.0819 & $<0.0001$ \\
socialprotection_2 & 0.1921 & 0.0904 & 0.0335 \\
\hline
\end{tabular}

Notes:

Number of observations $=250,25$ cross-sectional data units enabled, dependent variable: GiniGap.

Source: Own preparation.

\section{Chart 1.}

Redistribution in selected EU countries in 2007 and 2016 (in \%)

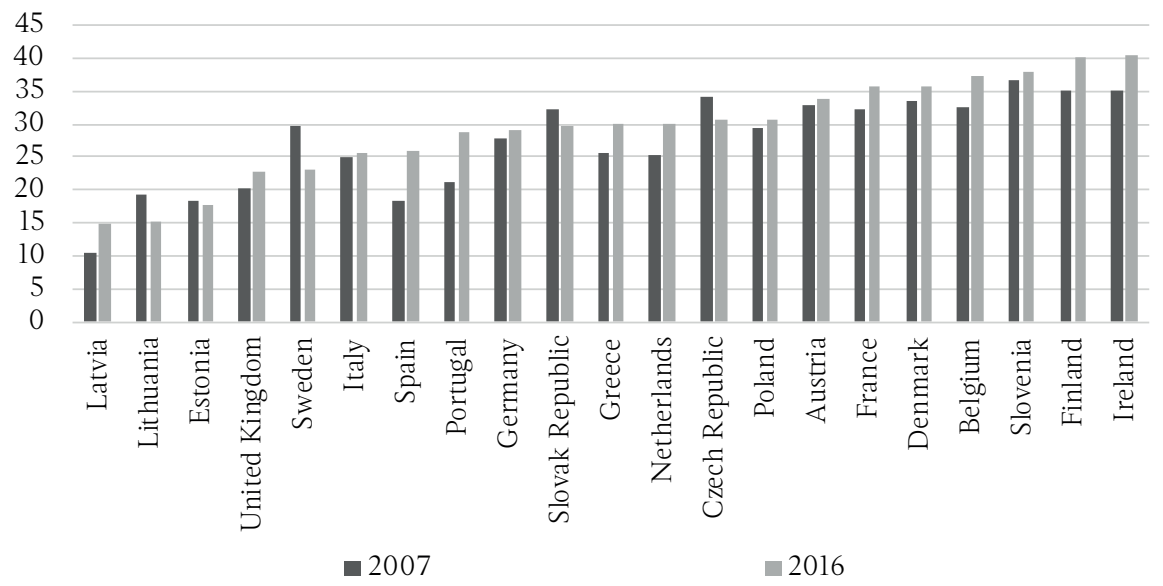

Source: Own preparation based on OECD (2019). 


\section{Chart 2.}

Inequalities within working-age population before and after tax and transfers (left axis), redistribution (right axis, in \%) in selected EU countries in 2016

60 50

50

40

30

20

10

0

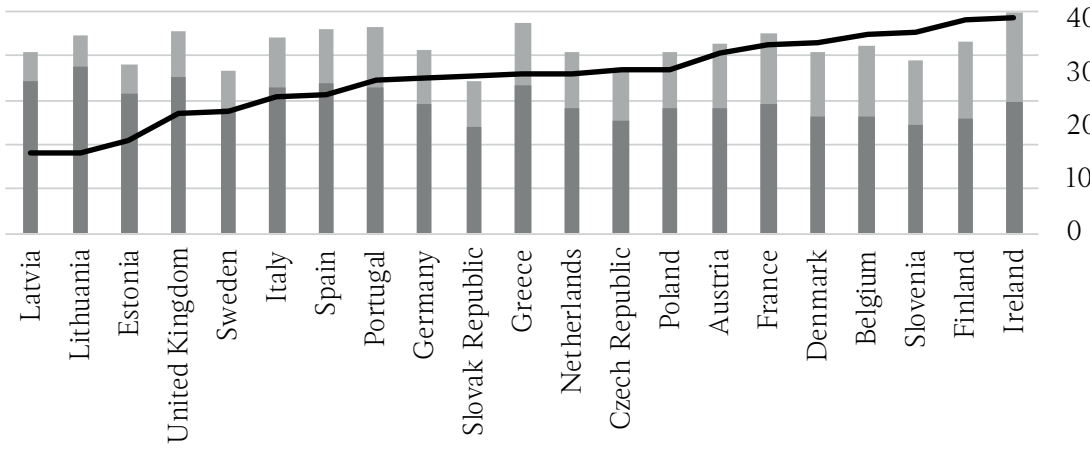

inequality before taxes and transfers

inequality after taxes and transfers

redistribution

Source: Own preparation based on OECD (2019). 
